\title{
Synthetic, Structural, and Biochemical Studies of Organotin(IV) With Schiff Bases Having Nitrogen and Sulphur Donor Ligands
}

\author{
Har Lal Singh ${ }^{1}$ and A. K. Varshney ${ }^{2}$ \\ ${ }^{1}$ Department of Chemistry, Shekhawati Engineering College, Jhunjhunu, Dundlod 333702, Rajasthan, India \\ ${ }^{2}$ Department of Chemistry, University of Rajasthan, Jaipur 302004, Rajasthan, India
}

Received 13 June 2005; Revised 2 August 2005; Accepted 19 September 2005

Three bidentate Schiff bases having nitrogen and sulphur donor sequences were prepared by condensing S-benzyldithiocarbazate $\left(\mathrm{NH}_{2} \mathrm{NHCS}_{2} \mathrm{CH}_{2} \mathrm{C}_{6} \mathrm{H}_{5}\right)$ with heterocyclic aldehydes. The reaction of diphenyltin dichloride with Schiff bases leads to the formation of a new series of organotin(IV) complexes. An attempt has been made to prove their structures on the basis of elemental analyses, conductance measurements, molecular weights determinations, UV, infrared, and multinuclear magnetic resonance $\left({ }^{1} \mathrm{H},{ }^{13} \mathrm{C}\right.$, and ${ }^{119} \mathrm{Sn}$ ) spectral studies. Organotin(IV) complexes were five- and six-coordinate. Schiff bases and their corresponding organotin complexes have also been screened for their antibacterial and antifungal activities and found to be quite active in this respect.

Copyright (c) 2006 H. L. Singh and A. K. Varshney. This is an open access article distributed under the Creative Commons Attribution License, which permits unrestricted use, distribution, and reproduction in any medium, provided the original work is properly cited.

\section{INTRODUCTION}

The number and diversity of nitrogen and sulfur chelating agents used to prepare new coordination and organometallic compounds has increased rapidly during the past few years [1-7]. The dithiocarbazate $\left(\mathrm{NH}_{2} \mathrm{NHCS}_{2}{ }^{-}\right)$and its substituted derivatives have been investigated [8-17]. These compounds have received much attention and for further studies because (i) they provide an interesting series of ligands whose properties can be greatly modified by introducing different organic substituents, thereby causing a variation in the ultimate donor properties, (ii) the interaction of these donors with metal ions gives complexes of different geometries and properties, and (iii) these complexes are potentially biologically active.

Keeping this in view, it was considered worthwhile to synthesize tin complexes of some stereochemical as well as biological importance. During the course of the present investigations, an attempt has been made to synthesize tin complexes by interacting $\mathrm{Ph}_{2} \mathrm{SnCl}_{2}$ and nitrogen, sulfur containing Schiff bases derived by condensation of heterocyclic aldehydes with S-benzyldithiocarbazate.

\section{EXPERIMENTAL}

Chemicals and solvents used were dried and purified by standard methods and moisture was excluded from the glass apparatus using $\mathrm{CaCl}_{2}$ drying tubes. Melting points were determined in open capillaries and are uncorrected. The ligands were prepared by the condensation of aldehydes with S-benzyldithiocarbazate as described earlier [18].

\section{Syntheses of $P h_{2} \operatorname{Sn}\left(L^{l-3}\right) C I$}

To a solution of sodium methoxide [sodium methoxide prepared by sodium metal $(0.10 \mathrm{~g} ; 0.0044$ mole $)$ in $5 \mathrm{~mL}$ of methanol] a benzene solution of ligands (1.43-1.21 g; 0.0044 mole) was added and the reaction mixture was refluxed for about 4 hours, at this stage, a benzene solution of $\mathrm{Ph}_{2} \mathrm{SnCl}_{2}$ (1.51 g; 0.0044 mole) was added to the above solution drop by drop and the reaction mixture was starred along with refluxing for about 6 hours. After cooling, the precipitated $\mathrm{NaCl}$ was filtered off through G-4 alkoxy funnel. Excess solvent was removed from the filtrate and the compound was finally dried in vacuum and a colored sticky solid was obtained. These were then repeatedly washed with dry cyclohexene and petroleum ether and these complexes were purified by recrystallization from the same solvent (Table 1).

\section{Syntheses of $\mathrm{Ph}_{2} \mathrm{Sn}\left(\mathrm{L}^{1-3}\right) 2$}

To a solution of sodium methoxide [sodium methoxide prepared by sodium metal $(0.02 \mathrm{~g} ; 0.0052 \mathrm{~mole})$ in $10 \mathrm{~mL}$ 
TABLE 1: Physical properties and analytical data of organotin(IV) complexes.

\begin{tabular}{|c|c|c|c|c|c|c|c|c|c|c|c|c|}
\hline \multirow{2}{*}{$\begin{array}{l}\text { Tin } \\
\text { compound }\end{array}$} & \multirow[b]{2}{*}{ Ligands } & \multirow{2}{*}{$\begin{array}{l}\text { Molar } \\
\text { ratio }\end{array}$} & \multirow{2}{*}{$\begin{array}{l}\text { Products color } \\
\text { and state }\end{array}$} & \multirow{2}{*}{$\begin{array}{l}\text { Yield } \\
\%\end{array}$} & \multirow{2}{*}{$\begin{array}{l}\mathrm{MP} \\
{ }^{\circ} \mathrm{C}\end{array}$} & \multicolumn{6}{|c|}{ Analyses \% found (calcd) } & \multirow{2}{*}{$\begin{array}{l}\text { Mol wt } \\
\text { found } \\
\text { (calcd) }\end{array}$} \\
\hline & & & & & & Sn & $\mathrm{C}$ & $\mathrm{H}$ & $\mathrm{N}$ & $S$ & $\mathrm{CI}$ & \\
\hline $\mathrm{Ph}_{2} \mathrm{SnCl}_{2}$ & $\mathrm{~L}^{1} \mathrm{H}$ & $1: 1$ & $\begin{array}{c}\mathrm{Ph}_{2} \mathrm{Sn}(\mathrm{Cl}) \mathrm{L}^{1} \\
\text { Dark brown solid }\end{array}$ & 75 & 82 & $\begin{array}{c}18.72 \\
(18.76)\end{array}$ & $\begin{array}{c}55.00 \\
(55.04)\end{array}$ & $\begin{array}{c}3.79 \\
(3.82)\end{array}$ & $\begin{array}{c}6.51 \\
(6.64)\end{array}$ & $\begin{array}{c}10.03 \\
(10.13)\end{array}$ & $\begin{array}{c}5.54 \\
(5.60)\end{array}$ & $\begin{array}{c}620 \\
(632)\end{array}$ \\
\hline $\mathrm{Ph}_{2} \mathrm{SnCl}_{2}$ & $\mathrm{~L}^{1} \mathrm{H}$ & $1: 2$ & $\begin{array}{l}\mathrm{Ph}_{2} \mathrm{Sn}\left(\mathrm{L}^{1}\right)_{2} \\
\text { Violet solid }\end{array}$ & 88 & 176 & $\begin{array}{c}12.83 \\
(12.88)\end{array}$ & $\begin{array}{c}59.85 \\
(59.94)\end{array}$ & $\begin{array}{c}4.11 \\
(4.15)\end{array}$ & $\begin{array}{c}9.01 \\
(9.11)\end{array}$ & $\begin{array}{c}13.82 \\
(13.90)\end{array}$ & - & $\begin{array}{c}912 \\
(921)\end{array}$ \\
\hline $\mathrm{Ph}_{2} \mathrm{SnCl}_{2}$ & $\mathrm{~L}^{2} \mathrm{H}$ & $1: 1$ & $\begin{array}{c}\mathrm{Ph}_{2} \mathrm{Sn}(\mathrm{Cl}) \mathrm{L}^{2} \\
\text { Yellowish solid }\end{array}$ & 81 & 108 & $\begin{array}{c}19.73 \\
(19.79)\end{array}$ & $\begin{array}{c}50.00 \\
(50.07)\end{array}$ & $\begin{array}{c}3.47 \\
(3.53)\end{array}$ & $\begin{array}{c}4.53 \\
(4.66)\end{array}$ & $\begin{array}{c}15.95 \\
(16.02)\end{array}$ & $\begin{array}{c}5.79 \\
(5.91)\end{array}$ & $\begin{array}{c}588 \\
(599)\end{array}$ \\
\hline $\mathrm{Ph}_{2} \mathrm{SnCl}_{2}$ & $\mathrm{~L}^{2} \mathrm{H}$ & $1: 2$ & $\begin{array}{l}\mathrm{Ph}_{2} \mathrm{Sn}\left(\mathrm{L}^{2}\right)_{2} \\
\text { Brown solid }\end{array}$ & 78 & 132 & $\begin{array}{c}13.82 \\
(13.87)\end{array}$ & $\begin{array}{c}53.20 \\
(53.34)\end{array}$ & $\begin{array}{c}3.71 \\
(3.77)\end{array}$ & $\begin{array}{c}6.44 \\
(6.54)\end{array}$ & $\begin{array}{c}22.38 \\
(22.47)\end{array}$ & - & $\begin{array}{c}850 \\
(855)\end{array}$ \\
\hline $\mathrm{Ph}_{2} \mathrm{SnCl}_{2}$ & $\mathrm{~L}^{3} \mathrm{H}$ & $1: 1$ & $\begin{array}{l}\mathrm{Ph}_{2} \mathrm{Sn}(\mathrm{Cl}) \mathrm{L}^{3} \\
\text { Yellow solid }\end{array}$ & 87 & 170 & $\begin{array}{c}20.30 \\
(20.34)\end{array}$ & $\begin{array}{c}51.39 \\
(51.44)\end{array}$ & $\begin{array}{c}3.57 \\
(3.62)\end{array}$ & $\begin{array}{c}4.68 \\
(4.79)\end{array}$ & $\begin{array}{c}10.87 \\
(10.98)\end{array}$ & $\begin{array}{c}5.96 \\
(6.07)\end{array}$ & $\begin{array}{c}568 \\
(583)\end{array}$ \\
\hline $\mathrm{Ph}_{2} \mathrm{SnCl}_{2}$ & $\mathrm{~L}^{3} \mathrm{H}$ & $1: 2$ & $\begin{array}{l}\mathrm{Ph}_{2} \mathrm{Sn}\left(\mathrm{L}^{3}\right)_{2} \\
\text { Yellow solid }\end{array}$ & 80 & 182 & $\begin{array}{c}14.28 \\
(14.41)\end{array}$ & $\begin{array}{c}56.37 \\
(56.42)\end{array}$ & $\begin{array}{c}3.82 \\
(3.91)\end{array}$ & $\begin{array}{c}6.72 \\
(6.80)\end{array}$ & $\begin{array}{c}15.50 \\
(15.56)\end{array}$ & - & $\begin{array}{c}801 \\
(823)\end{array}$ \\
\hline
\end{tabular}

TABLE 2: Important IR spectral data $\left(\mathrm{cm}^{-1}\right)$ of Schiff bases and their corresponding organotin(IV) complexes.

\begin{tabular}{|c|c|c|c|c|c|c|c|}
\hline Compounds & $\nu(\mathrm{C}=\mathrm{N})$ & $\nu(\mathrm{NH})$ & $\nu(\mathrm{C}-\mathrm{S})$ & $v(\mathrm{~N}-\mathrm{N})$ & $\nu(\mathrm{Sn} \leftarrow \mathrm{N})$ & $v(\mathrm{Sn}-\mathrm{S})$ & $v(\mathrm{Sn}-\mathrm{Cl})$ \\
\hline $\mathrm{L}^{1} \mathrm{H}$ & 1618 & 3168 & 1315 & 940 & - & - & - \\
\hline $\mathrm{Ph}_{2} \mathrm{Sn}(\mathrm{CI}) \mathrm{L}^{1}$ & 1599 & - & 1319 & 945 & 418 & 335 & 302 \\
\hline $\mathrm{Ph}_{2} \mathrm{Sn}\left(\mathrm{L}^{1}\right)_{2}$ & 1606 & - & 1321 & 947 & 412 & 332 & - \\
\hline $\mathrm{L}^{2} \mathrm{H}$ & 1621 & 3201 & 1317 & 938 & - & - & - \\
\hline $\mathrm{Ph}_{2} \mathrm{Sn}(\mathrm{Cl}) \mathrm{L}^{2}$ & 1594 & - & 1320 & 942 & 425 & 328 & 305 \\
\hline $\mathrm{Ph}_{2} \mathrm{Sn}\left(\mathrm{L}^{2}\right)_{2}$ & 1602 & - & 1324 & 945 & 416 & 333 & - \\
\hline $\mathrm{L}^{3} \mathrm{H}$ & 1620 & 3380 & 1309 & 939 & - & - & - \\
\hline $\mathrm{Ph}_{2} \mathrm{Sn}(\mathrm{Cl}) \mathrm{L}^{3}$ & 1603 & - & 1315 & 944 & 419 & 230 & 298 \\
\hline $\mathrm{Ph}_{2} \mathrm{Sn}\left(\mathrm{L}^{3}\right)_{2}$ & 1609 & - & 1318 & 947 & 412 & 334 & - \\
\hline
\end{tabular}

of methanol] a benzene solution of ligands (1.69-1.44 g; 0.0052 mole) was added and the reaction mixture was refluxed for about 4 hours, at this stage, a benzene solution of $\mathrm{Ph}_{2} \mathrm{SnCl}_{2}$ (0.89 g; 0.0026 mole) was added to the above solution drop by drop and the reaction mixture was starred along with refluxing for about 6 hours. After cooling, the precipitated $\mathrm{NaCl}$ was filtered off through G-4 alkoxy funnel. Excess solvent was removed from the filtrate and the compound was finally dried in vacuum and a colored sticky solid was obtained. These were then repeatedly washed with dry cyclohexene and petroleum ether and these complexes were purified by recrystallization from the same solvent. The synthetic and analytical data of the resulting complexes are recorded in Table 1. For tin, carbon, hydrogen, sulfur, nitrogen, and chlorine agree with the theoretical values within the limit of experimental error.

\section{Analytical methods}

Tin was estimated gravimetrically as $\mathrm{SnO}_{2}$ and chlorine was estimated volumetrically using Volhard's method [19]. Nitrogen and sulphur were estimated by Kjeldahl's and
Messenger's methods, respectively [20]. Molar conductance measurements were made in anhydrous DMF at $36 \pm 1^{\circ} \mathrm{C}$ using a systronics conductivity bridge modle-305. Molecular weight determinations were carried out by the Rast camphor method.

\section{Spectral measurements}

The electronic spectra were recorded in methanol on a Toshniwal spectrophotometer. Infrared spectra were obtained on a Perkin-Elmer 577 grating spectrophotometer as $\mathrm{Nu}$ jol mulls and $\mathrm{KBr}$ optics. ${ }^{1} \mathrm{H},{ }^{13} \mathrm{C}$, and ${ }^{119} \mathrm{Sn}$ NMR spectra were recorded in $\mathrm{CDCl}_{3}$ solution and $\mathrm{CHCl}_{3}$ solution, respectively, on a Jeol Fx-90 Q spectrometer. TMS has been used as an internal reference for ${ }^{1} \mathrm{H}$ and ${ }^{13} \mathrm{C}$ NMR. For ${ }^{119} \mathrm{Sn}$ NMR, TMT (tetramethyltin) has been used as an external reference.

\section{RESULTS AND DISCUSSION}

Schiff bases were prepared by the stoichiometric reactions of S-benzyldithiocarbazate with heterocyclic aldehydes, which 


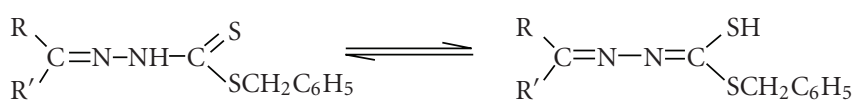

Scheme 1: Tautomeric equilibrium between the two forms indicated.

were potentially bidentate. The complexes formed from the different molar reactions of diphenyltin dichloride with monofunctional bidentate ligands can be represented by the following equations:

$$
\begin{aligned}
\mathrm{Ph}_{2} \mathrm{SnCl}_{2}+\mathrm{NSH}+\mathrm{CH}_{3} \mathrm{ONa} & \longrightarrow \mathrm{Ph}_{2} \mathrm{Sn}(\mathrm{NS}) \mathrm{Cl}+\mathrm{NaCl} \\
\mathrm{Ph}_{2} \mathrm{SnCl}_{2}+2 \mathrm{NSH}+2 \mathrm{CH}_{3} \mathrm{ONa} & \longrightarrow \mathrm{Ph}_{2} \mathrm{Sn}(\mathrm{NS})_{2}+2 \mathrm{NaCl}
\end{aligned}
$$

where NSH represents the Schiff bases ligands.

The above reactions are quite facile and could be completed in 6-8 hours of refluxing. The resulting new derivatives are obtained as colored sticky solid and are mostly soluble in common organic solvents, DMSO and DMF. The molar conductances of $10^{-3} \mathrm{M}$ solutions of the compounds in DMSO are in the range $9-18 \mathrm{Ohm}^{-1} \mathrm{~cm}^{2} \mathrm{~mol}^{-1}$ indicating their nonelectrolytic nature. The molecular weights of the compounds determined by the Rast camphor mothod correspond to the formula weight, indicating monomeric nature.

\section{Infrared spectra}

The infrared spectra of ligands [18] show a strong band in the region $3450-3180 \mathrm{~cm}^{-1}$ attributable to $\nu(\mathrm{NH})$, while the band at $\sim 2570 \mathrm{~cm}^{-1}$ due to $\nu(\mathrm{SH})$ does not appear. However, it is observed in the solution spectra with $\mathrm{NH}$ frequency disappearing, indicating that there exists a tautomeric equilibrium $[18,21]$ between the two forms as indicated in Scheme 1. In these complexes, this band is absent showing thereby coordination of sulphur to the metal by the loss of thiolic protons of the ligands. A medium intensity band at $\sim 1315 \mathrm{~cm}^{-1}$ due to the $\nu(\mathrm{C}-\mathrm{S})$ vibration is split on complexation suggesting the participation of the sulphur atom in coordination.

A band of medium to strong intensity at $\sim 1600 \mathrm{~cm}^{-1}$ in the complexes may be assigned to the $v(\mathrm{C}=\mathrm{N})[22,23]$ vibration and which originally appeared in the region at $\sim 1610 \mathrm{~cm}^{-1}$ in the both the solution and solid states. The shift of this band to the lower side indicates coordination of the azomethine nitrogen to the metal atom. The occurrence of the $v(\mathrm{~N}-\mathrm{N})$ and $v(\mathrm{C}-\mathrm{S})$ bands at a higher frequency in the IR spectra of the complexes as compared to the ligands suggests a reduction of the repulsion between the lone pair of the nitrogen atom [24] as a result of coordination via the azomethine nitrogen.

Besides, several new bands in the complexes observed at $\sim 420 \mathrm{~cm}^{-1}$ and $\sim 332 \mathrm{~cm}^{-1}$ may be assigned to $\nu(\mathrm{Sn} \leftarrow \mathrm{N})$ [25] and $\nu(S n-S)$ [26], respectively. Finally, in the case of $\mathrm{Ph}_{2} \mathrm{Sn}(\mathrm{L}) \mathrm{Cl}$ type of complexes, a band of medium intensity around at $\sim 302 \mathrm{~cm}^{-1}$ is due to $v(\mathrm{Sn}-\mathrm{Cl})$ vibration [27].

\section{Electronic spectra}

In the electronic spectra of the ligands $[18,28]$ a band at $\sim 216 \mathrm{~nm}$ is observed which may be assigned to the lB band of the phenyl ring. This shifts to longer wavelength on complexation and is observed at $\sim 232 \mathrm{~nm}$ in the complexes. Also, the ligands chromophore $>\mathrm{C}=\mathrm{N}$, which is observed at $\sim 290 \mathrm{~nm}$, shifts to higher wavelength and is observed at $\sim 294 \mathrm{~nm}$ in the complexes. In the spectra of ligands, a band observed at $\sim 340 \mathrm{~nm}$ due to the secondary band of benzene and which gets red shifted due to the presence of $>\mathrm{C}=\mathrm{N}-\mathrm{N}=\mathrm{C}<$. However, this appears at $\sim 370 \mathrm{~nm}$ in the complexes possibly due to the polarization in $\mathrm{C}=\mathrm{N}$ bond caused by the metal-ligand electron interaction. Three sharp bands are observed in the region, 245-268 $\mathrm{nm}$ and assigned as charge-transfer bands, indicating the formation of $\sigma$ bond [29] and $(\mathrm{d} \pi-\mathrm{p} \pi)$ [30] bonds between p-orbitals of sulphur and vacant $5 \mathrm{~d}$ orbitals of tin.

\section{${ }^{1}$ H NMR spectra}

The above bonding pattern is further supported by proton magnetic resonance spectral studies of ligands and their corresponding tin complexes. The ${ }^{1} \mathrm{H}$ NMR spectra of the ligands [18] exhibit the $-\mathrm{CH}_{2}-$ protons signals at $\sim \delta 4.20$ $\mathrm{ppm}$, aromatic proton signal around $\delta 7.60-6.60 \mathrm{ppm}$, and it remains at the same position in the spectra of the metal complexes. The proton of NH group of the ligands gives a signal at $\sim \delta 10.82 \mathrm{ppm}$ which is absent in the spectra of metal complexes indicating the chelation of the ligand moiety to tin with the sulphur atom.

The signal at $\sim \delta 8.50 \mathrm{ppm}$ observed in the ligand is assigned to azomethine protons, which is shifted downfield in the spectra of corresponding tin complexes $(\sim \delta 9.02 \mathrm{ppm})$ on account of its deshielding which is attributed to the donation of the lone pair of electrons by the azomethine nitrogen to the tin atom.

\section{${ }^{13}$ C NMR spectra}

${ }^{13} \mathrm{C}$ NMR data have been recorded for all the ligands, namely, S-Benzyl- $\beta-\mathrm{N}$ (indlymethylidene) dithiocarbazate $\left(\mathrm{L}^{1} \mathrm{H}\right)$, SBenzyl- $\beta-\mathrm{N}$ (thienylmethylidene) dithiocarbazate $\left(\mathrm{L}^{2} \mathrm{H}\right)$, and S-Benzyl- $\beta-\mathrm{N}$ (furylmethylidene) dithiocarbazate $\left(\mathrm{L}^{3} \mathrm{H}\right)$ and its corresponding tin complexes (Table 3 ). The signals due to the carbon atoms attached to the thionic and the azomethine groups in ligands appear at $\delta \sim 190.3$ and $\sim 150.3 \mathrm{ppm}$, respectively. However, in the spectra of the corresponding tin complexes, these appear at $\delta \sim 172.8 \mathrm{ppm}$ (thionic group) and at $\delta \sim 160 \mathrm{ppm}$ (azomethine group), respectively. The considerable shifts in carbons attached to $\mathrm{S}$ and $\mathrm{N}$ indicate 
TABLE 3: ${ }^{13} \mathrm{C}$ NMR spectral data for ligands and their corresponding organotin(IV) complexes.

\begin{tabular}{|c|c|c|c|c|c|c|c|c|c|c|c|c|c|c|c|}
\hline \multirow{2}{*}{ Compounds } & \multicolumn{12}{|c|}{ Chemical shift in $\delta$ ppm } & \multicolumn{3}{|c|}{$\mathrm{Sn}-\mathrm{Ph}$} \\
\hline & $\mathrm{C}-2$ & $\mathrm{C}-3$ & $\mathrm{C}-4$ & C-5 & C-6 & $\mathrm{C}-7$ & $\mathrm{C}-8$ & C-9 & C-10 & C-11 & C-12 & Aromatic carbons & $\alpha$ & $\beta$ & $\gamma$ \\
\hline $\mathrm{L}^{1} \mathrm{H}$ & 137.1 & 135.4 & 123.5 & 122.8 & 120.4 & 119.2 & 110.7 & 167.7 & 150.1 & 194.3 & 39.2 & $136.8,126.8,128.3,127.5$ & & - & \\
\hline $\mathrm{Ph}_{2} \mathrm{Sn}(\mathrm{CI}) \mathrm{L}^{1}$ & 136.7 & 136.5 & 124.7 & 123.6 & 121.3 & 119.9 & 118.1 & 165.2 & 162.5 & 178.8 & 39.0 & $137.2,127.5,128.6,127.8$ & 133.3 & 30.5, & $27.4,129.3$ \\
\hline $\mathrm{Ph}_{2} \mathrm{Sn}\left(\mathrm{L}^{1}\right)_{2}$ & 136.9 & 136.8 & 123.8 & 123.3 & 120.8 & 119.7 & 115.4 & 166.1 & 160.7 & 175.4 & 38.2 & $136.9,127.2,128.0,127.6$ & 133.1 & 30.6, & $27.7,129.5$ \\
\hline $\mathrm{L}^{2} \mathrm{H}$ & 143.3 & 124.8 & 122.1 & 134.4 & 149.0 & 195.7 & 39.4 & - & - & 一 & - & $137.2,127.1,128.2,127.6$ & & - & \\
\hline $\mathrm{Ph}_{2} \mathrm{Sn}(\mathrm{CI}) \mathrm{L}^{2}$ & 142.6 & 122.6 & 121.0 & 136.1 & 164.1 & 175.7 & 39.2 & - & - & - & - & $137.5,128.9,128.4,127.9$ & 133.6 & 30.5 & $27.8,129.5$ \\
\hline $\mathrm{Ph}_{2} \mathrm{Sn}\left(\mathrm{L}^{2}\right)_{2}$ & 145.2 & 124.0 & 121.8 & 136.7 & 161.7 & 173.4 & 37.6 & - & - & - & - & $137.2,127.1,127.9,127.5$ & 134.1 & 30.7, & $27.4,129.9$ \\
\hline $\mathrm{L}^{3} \mathrm{H}$ & 141.8 & 125.4 & 124.7 & 127.6 & 151.3 & 198.5 & 38.7 & - & - & - & - & $137.4,127.5,128.6,127.1$ & & - & \\
\hline $\mathrm{Ph}_{2} \mathrm{Sn}(\mathrm{CI}) \mathrm{L}^{3}$ & 138.4 & 127.5 & 125.3 & 125.6 & 160.9 & 174.3 & 40.2 & - & - & - & - & $137.5,129.1,130.9,125.5$ & 133.5 & 30.6, & $127.7,129.3$ \\
\hline $\mathrm{Ph}_{2} \mathrm{Sn}\left(\mathrm{L}^{3}\right)_{2}$ & 138.9 & 127.9 & 126.9 & 128.0 & 158.6 & 170.8 & 43.0 & - & - & - & - & $135.8,127.6,127.53,126.3$ & 134.1 & 130.9, & $127.2,129.8$ \\
\hline
\end{tabular}<smiles>C=C(CCC)N/N=C/c1c[nH]c2ccccc12</smiles><smiles>C=C(CC)NN=Cc1ccc(CC)s1</smiles><smiles>C=C(CC)NN=Cc1ccco1</smiles>

the involvement of sulphur and nitrogen atoms in coordination. The carbons of phenyl groups $(\mathrm{Sn}-\mathrm{Ph})$ are observed at position comparable to other similar compounds.

\section{${ }^{119}$ Sn NMR spectra}

These $\mathrm{Ph}_{2} \mathrm{Sn}(\mathrm{Cl}) \mathrm{L}$ and $\mathrm{Ph}_{2} \mathrm{Sn}(\mathrm{L})_{2}$ complexes give sharp signals at $\sim 8-235.4 \mathrm{ppm}$ and $\sim \delta-456.8 \mathrm{ppm}$, respectively in ${ }^{119} \mathrm{Sn}$ NMR spectra and which strongly support the fiveand six-coordination around tin in a trigonal-bipyramidal and distorted octahedral geometry, respectively. Values [3133] for similar five- and six-coordinated organotin(IV) complexes have been reported in the ranges of $\delta-128$ to -268 ppm and $\delta-485$ to $-503 \mathrm{ppm}$, respectively.

On the basis of the observed spectral evidence, the tentative structures shown in Scheme 2 with (probably distorted) 

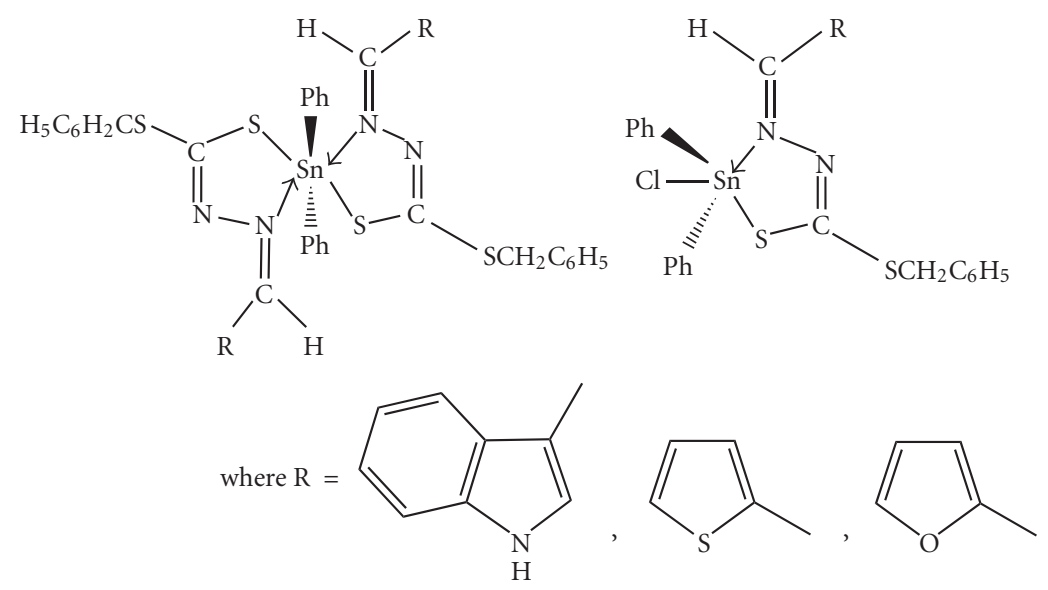

Scheme 2: Geometry of the organotin(IV) complexes.

TABLE 4: Antibacterial activity of Schiff bases and their corresponding organotin(IV) complexes.

\begin{tabular}{|c|c|c|c|c|c|c|c|}
\hline \multicolumn{2}{|c|}{ Microorganisms } & \multicolumn{6}{|c|}{ Compounds ${ }^{c}$} \\
\hline & & $\mathrm{L}^{1} \mathrm{H}$ & $\mathrm{Ph}_{2} \mathrm{Sn}(\mathrm{CI}) \mathrm{L}^{1}$ & $\mathrm{Ph}_{2} \mathrm{Sn}\left(\mathrm{L}^{1}\right)_{2}$ & $\mathrm{~L}^{2} \mathrm{H}$ & $\mathrm{Ph}_{2} \mathrm{Sn}(\mathrm{CI}) \mathrm{L}^{2}$ & $\mathrm{Ph}_{2} \mathrm{Sn}\left(\mathrm{L}^{2}\right)_{2}$ \\
\hline E coli & $\mathrm{IZ}^{\mathrm{a}}(\mathrm{AI})^{\mathrm{b}}$ & $18.01(0.60)$ & $22.62(0.75)$ & $25.01(0.83)$ & $15.33(0.51)$ & $18.01(0.60)$ & $20.20(0.67)$ \\
\hline S aureus & $\mathrm{IZ}^{\mathrm{a}}(\mathrm{AI})^{\mathrm{b}}$ & $20.14(0.75)$ & $24.41(0.90)$ & $28.78(1.10)$ & $18.52(0.69)$ & $22.44(0.83)$ & $26.69(1.06)$ \\
\hline B thurengiensis & $\mathrm{IZ}^{\mathrm{a}}(\mathrm{AI})^{\mathrm{b}}$ & $22.31(0.79)$ & $26.32(0.94)$ & $26.52(1.05)$ & $22.38(0.80)$ & $29.79(0.92)$ & $29.01(1.04)$ \\
\hline K pneullleniae & $\mathrm{IZ}^{\mathrm{a}}(\mathrm{AI})^{\mathrm{b}}$ & $19.20(0.66)$ & $25.02(0.86)$ & $28.72(0.99)$ & $17.45(0.60)$ & $20.66(0.71)$ & $24.42(0.84)$ \\
\hline
\end{tabular}

${ }^{\mathrm{a}} \mathrm{IZ}=$ inhibition zone $(\mathrm{mm}),{ }^{\mathrm{b}}(\mathrm{AI})=$ inhibition zone of test compounds/inhibition zone of standard, ${ }^{\mathrm{c}}$ see Table 1 for identities of ligands $[18] \mathrm{L}^{1} \mathrm{H}-\mathrm{L}^{2} \mathrm{H}$ and their corresponding organotin(IV) complexes.

trigonal-bipyramidal and octahedral geometries can be proposed.

\section{BIOLOGICAL STUDIES}

\section{Antibacterial activity}

In vitro antibactericidal activity of the ligands and their corresponding organotin complexes were tested by the paper disc diffusion method $[34,35]$ at $200 \mathrm{mg} / \mathrm{L}$ concentration in methanol. Streptomycin was used as reference compound for antibacterial activities. Escherichia coli, Staphylococcus aureus, Klebsiella pneumeniae, and Bacillus thurengiensis were used as the test organisms. The discs having a diameter of $4 \mathrm{~mm}$ were soaked in these solutions. These discs were placed on an appropriate medium previously seeded with organisms in petri plates and stored in an incubator at $30 \pm 1{ }^{\circ} \mathrm{C}$. The inhibition zone around each disc was measured after 24 hours. Results have been recorded in the form of inhibition zones (diameter, mm) and activity indices in Table 4.

\section{Antifungal activity}

The above-mentioned compounds were also screened for their antifungal activity on Aspergillus niger, Rhizoctonia phaseoli, and Penicillium crysogenes. The compounds were directly mixed with the medium (potato, dextrose, agar, and distilled water) in different concentrations and the linear growth of the fungus was obtained by measuring the fungal colony diameter after 96 hours (Table 5). The amount of growth inhibition in all the replicates was recorded and calculated by the following equation:

$$
\text { percentage of inhibition }=(C-T) \times \frac{100}{C},
$$

where $C=$ diameter of fungal colony in control plate and $T=$ diameter of fungal colony in test plate.

Further, the organotin complexes are more active than the free ligands, which indicates that metallation increases antimicrobial activity. The above studies indicate that the organotin complexes synthesized in the present studies are highly active against all these microorganisms. The results reported in Tables 4 and 5 reveal that the organotin complexes of dithiocarbazates are more active for all organisms than corresponding semicarbazones and thiosemicarbazones complexes reported in our earlier publications [26], and this also indicates that sulphur is more effective than oxygen as suggested by Tandon [36]. The increase in the activity of tin $(\mathrm{lV})$ complexes as compared to the parent ligand may be 
TABLE 5: Antifungal activity of Schiff bases and their corresponding organotin(IV) complexes.

\begin{tabular}{lcccccc}
\hline \multirow{2}{*}{ Compounds } & \multicolumn{5}{c}{ Average percentage after 96 hours } \\
\cline { 2 - 7 } & \multicolumn{2}{c}{ A niger } & \multicolumn{5}{c}{ R phaseoli } & \multicolumn{2}{c}{ P clysogenes } \\
\cline { 2 - 7 } & $0.01 \%$ & $0.1 \%$ & $0.01 \%$ & $0.1 \%$ & $0.01 \%$ & $0.1 \%$ \\
\hline $\mathrm{L}^{1} \mathrm{H}$ & 40 & 52 & 34 & 42 & 28 & 36 \\
$\mathrm{Ph}_{2} \mathrm{Sn}(\mathrm{CI}) \mathrm{L}^{1}$ & 55 & 55 & 40 & 50 & 38 & 42 \\
$\mathrm{Ph}_{2} \mathrm{Sn}\left(\mathrm{L}^{1}\right)_{2}$ & 57 & 57 & 42 & 55 & 41 & 36 \\
$\mathrm{~L}^{2} \mathrm{H}$ & 38 & 47 & 31 & 40 & 32 & 50 \\
$\mathrm{Ph}_{2} \mathrm{Sn}(\mathrm{CI}) \mathrm{L}^{2}$ & 49 & 58 & 35 & 45 & 48 & 53 \\
$\mathrm{Ph}_{2} \mathrm{Sn}\left(\mathrm{L}^{2}\right)_{2}$ & 52 & 60 & 38 & 42 & 49 & \\
\hline
\end{tabular}

due to the chelate formation in which the ligand is coordinated to the central tin atom through the thioketonic sulphur and azomethine nitrogen leading to an increased fungitoxic action. The compounds containing a halogen atom attached directly to the central atom also showed moderate activity, but the replacement of halogen by another ligand moiety enhances the biochemical properties of the whole molecules. Almost all the compounds were found to be more active against all the microorganisms used than the ligands themselves. The mode of action of the compounds may involve the formation of a halogen bond though $(-\mathrm{N}=\mathrm{C}-\mathrm{S})$ [37] groups with the active centers of the cell constituents resulting in an interference with the cell process. The screening data of a particular ligand and its metal complexes show that the former has greater activity than the later from the biochemical point of view. On comparing the results in general, it may be concluded that the organotin(IV) complexes have greater inhibiting power than the free ligands against all the microbes.

Although, it is difficult to make out an exact structureactivity relationship between the microbial activity and the structure of these complexes, it can possibly be concluded that the chelation as well as addition of a substrate enhance the activity of the complexes. The variation in the toxicity of different antibacterial agents against different organisms as suggested by Garrod et al [38] depends either on the impermeability of the cell or differences in ribosomes to the antimicrobial agent. Though the results suggest that the ligands have remarkable toxic property, their complexes of tin inhibit the growth of organisms to a greater extent. This is in accordance with the earlier reports [39]. Further, the greater activity of the complexes can also be explained on the basis of their higher solubility of the particles.

\section{ACKNOWLEDGMENTS}

We thank the Head of Department of chemistry, University of Rajasthan, Jaipur, for the provided laboratory facilities. One of the authors (H. L. Singh) wishes to thank the Council of Scientific Industrial Research, New Delhi, for financial assistance.

\section{REFERENCES}

[1] Ali MA, Ibrahim NEH, Butcher RJ, Jasinski JP, Jasinski JM, Bryan JC. Synthesis and characterization of some four- and five-coordinate copper(II) complexes of 6-methyl2-formylpyridinethiosemicarbazone (HNNS) and the X-ray crystal structures of the $\left[\mathrm{Cu}(\mathrm{NNS})\left(\mathrm{CH}_{3} \mathrm{COO}\right)\left(\mathrm{H}_{2} \mathrm{O}\right)\right]$ and $[\mathrm{Cu}$ ( $\left.\mathrm{HNNS})\left(\mathrm{H}_{2} \mathrm{O}\right)\left(\mathrm{SO}_{4}\right)\right] \cdot \mathrm{H}_{2} \mathrm{O}$ complexes. Polyhedron. 1998;17(11-12):1803-1809.

[2] Ali MA, Haroon CM, Uddin MN, Majumder SMMH, Tarafder MTH, Khair MA. Synthesis, characterization and biological activities of some new nickel (II) complexes of quadridentate SNNS ligands. Transition Metal Chemistry. 1992;17:133.

[3] Ali MA, Intan-Safinar I, Mackeen MM, et al. Bioassay-guided isolation of deoxypodophyllotoxin, the cytotoxic constituents of Juniperus chinensis. Natural Product Sciences. 1998;4(3):180.

[4] Ali MA, Livingstone SE. Metal complexes of sulphur-nitrogen chelating agents. Coordination Chemistry Reviews. 1974;13(23):101-132.

[5] Gupta MK, Singh HL, Varshney S, Varshney AK. Synthetic and spectroscopic characterization of organotin(IV) complexes of biologically active Schiff bases derived from sulpha drugs. Bioinorganic Chemistry \& Applications. 2003;1(3-4):309-320.

[6] Ali MA, Hossain SMG, Majumder SMMH, Uddin MN, Tarafder MTH. Synthesis and characterization of some new nickel(II), zinc(II) and cadmium(II) complexes of quadridentate SNNS ligands. Polyhedron. 1987;6(8):1653-1656.

[7] Ali MA, Majumder SMMH, Butcher RJ, Jasinski JP, Jasinski JM. The preparation and characterization of bischelated nickel(II) complexes of the 6-methylpyridine-2carboxaldehyde Schiff bases of S-alkyldithiocarbazates and the X-ray crystal structure of the bis $\{\mathrm{S}$-methyl- $\beta-N$ - $(6-$ methylpyrid-2-yl)-methylenedithiocarbazato nickel(II) complex. Polyhedron. 1997;16(16):2749-2754.

[8] Ali MA, Dey KK, Uddin MN, et al. The preparation and characterization of some copper(II) complexes of the 6methyl-2-formylpyridine thiosemicarbazone and the X-ray crystal structure of the chloro(6-methyl-2-formylpyridinethiosemicabazonato) copper(II) complex. Polyhedron. 1996;15 (19):3331-3339.

[9] Ali MA, Kabir MH, Uddin MN, Mazumder SMMH, Tarafder MTH, Khair MA. Synthesis, characterization and antifugal properties of some four- coordinate nickel(II) and four and five coordinate copper(II) complexes containing tridentate 
thiosemicarbozones and heterocyclic bases. Indian Journal of Chemistry. 1988;27A:1064.

[10] Ali MA, Uddin MN, Uddin MM, Chowdhury DA II, Tarafder MTH. Magnetic and spectroscopic studies on metal complexes of ONS donor ligands: nickel(II) and copper(II) complexes of Schiff bases formed by condensation of 2hydroxybenzaldehyde with $S S^{\prime}$-dibenzyldithiocarbazate and $S$-methyl-S'-benzyldithiocarbazate. Indian Journal of Chemistry. 1986;25A:238.

[11] Ali MA, Tarafder MTH. Metal complexes of sulphur and nitrogen-containing ligands: complexes of s-benzyldithiocarbazate and a Schiff base formed by its condensation with pyridine-2-carboxaldehyde. Journal of Inorganic and $\mathrm{Nu}$ clear Chemistry. 1977;39(10):1785-1791.

[12] Hossain ME, Alam MN, Begum J, et al. The preparation, characterization, crystal structure and biological activities of some copper(II) complexes of the 2-benzoylpyridine Schiff bases of S-methyl- and S-benzyldithiocarbazate. Inorganica Chimica Acta. 1996;249(2):207-213.

[13] Tarafder MTH, Ali MA. Chelates of nickel(II) and copper(II) with tridentate Schiff base formed by the condensation of S-benzyldithiocarbazate with benzoin. Canadian Journal of Chemistry. 1978;56:2000.

[14] Tarafder MTH, Roy S. Metal complexes of some nitrozensulfur donor ligands. Indian Journal of Chemistry. 1988;27A: 407.

[15] Tarafder MTH. Ni(II), $\mathrm{Cu}(\mathrm{II})$ and $\mathrm{Zn}(\mathrm{II})$ complexes of quadridentate S,N,N,S, donor Schiff base derived from Sbenzyldithiocarbazate and benzil. Indian Journal of Chemistry. 1989;28A:531.

[16] Tarafder MTH, Miah MAJ, Bose RN, Ali MA. Metal complexes of some Schiff bases derived from s-benzyldithiocarbazate. Journal of Inorganic and Nuclear Chemistry. 1981;43(12):31513157.

[17] Tarafder MTH, Rahim M. Nickel(II) complexes of S-benzyl- $\beta$ $N$-(furyl)methylenedithiocarbazate. Indian Journal of Chemistry. 1989;28A:1105.

[18] Singh HL, Varshney AK. Synthesis and characterization of coordination compounds of organotin(IV) with nitrogen and sulfur donor ligands. Applied Organometallic Chemistry. 2001;15(9):762-768.

[19] Furnis BS, Hannaford AJ, Smith PWG, Tatchell AR. Vogel's Textbook of Practical Organic Chemistry. 5th ed. London, UK: Longman; 1989.

[20] Ali MA, Livingstone SE, Philips DJ. Metal chelates of dithiocarbazic acid and its derivatives. VI. Antiferromagnetic and ferromagnetic interactions in some copper(II) complexes of salicylaldehyde and acetylacetone Schiff bases derived from smethyldithiocarbazate. Inorganica Chimica Acta. 1973;7:179186.

[21] Saxena AK, Koacher JK, Tandon JP. Electron impact induced fragmentation studies on some diorganotin complexes of scontaining Schiff bases. Inorganic and Nuclear Chemistry Letters. 1981;17(7-8):229-233.

[22] Kovacic JE. The $\mathrm{C}=\mathrm{N}$ stretching frequency in the infrared spectra of Schiff's base complexes-I. Copper complexes of salicylidene anilines. Spectrochimica Acta Part A: Molecular Spectroscopy. 1967;23(1):183-187.

[23] Saxena A, Tandon JP, Molloy KC, Zuckerman JJ. Tin(IV) complexes of tridenate Schiff bases having ONS donor system. Inorganic Chimica Acta. 1982;63:71.

[24] Lanfredi AMM, Tiripicchio A, Camellini MT, Monaci A, Tarli F. X-Ray and infrared structural studies on the methyl ester of dithiocarbazic acid and its $N$-substituted derivatives. Journal of the Chemical Society, Dalton Transactions. 1977;(5):417-422.

[25] Singh HL, Varshney S, Varshney AK. Organotin(IV) complexes of biologically active Schiff bases derived from heterocyclic ketones and sulpha drugs. Applied Organometallic Chemistry. 1999;13(9):637-641.

[26] Singh HL, Sharma M, Varshney AK. Synthesis and characterization of some tin(II) complexes with semicarbaxones and thiosemicarbazones of heterocyclic ketones. Synthesis and Reactivity in Inorganic and Metal-Organic Chemistry. 1999;29:817.

[27] Pettinari C, Pellei M, Cingolani A, et al. Synthesis, spectroscopic, and X-ray diffraction structural studies of tin(IV) derivatives with tris(pyrazol-1-yl)methanes. Inorganic Chemistry. 1999;38(25):5777-5787.

[28] Das M, Livingstone SE. Metal chelates of dithiocarbazic acid and its derivatives. IX. Metal chelates of ten new Schiff bases derived from S-methyldithiocarbazate. Inorganica Chimica Acta. 1976;19:5-10.

[29] Pardley SA, Gopinathan S, Gopinathan C. Titanium(IV) and organotin(IV) chelates of S-benzyl-D-N-(2-hydroxyphenyl) methylen dithiocarbazate. Indian Journal of Chemistry. 1980; 19A:130.

[30] Ali MA, Livingstone SE, Philips DJ. Metal chelates of dithiocarbazic acid and its derivatives. III. Complexes of the tridentate Schiff base $\alpha$-N-Methyl-S-methyl- $\beta-N-(2-$ pyridyl)methylendithiocarbazate with some $3 \mathrm{~d}$ metal ions. Inorganica Chimica Acta. 1972;6:11-16.

[31] Pettinari C, Pellei M, Miliani M, et al. Tin(IV) and organotin(IV) complexes containing mono or bidentate $\mathrm{N}$-donor ligands III. 1-methylimidazole derivatives: synthesis, spectroscopic and structural characterization. Journal of Organometallic Chemistry. 1998;553(1-2):345-369.

[32] Lockhart TP, Manders WF. Solid-state carbon-13 NMR investigation of methyltin(IV) compounds. Correlation of NMR parameters with molecular structure. Journal of the American Chemical Society. 1987;109(23):7015-7020.

[33] Pettinari C, Marchetti F, Cingolani A, Bartolini S. Tin(IV) and organotin(IV) complexes containing mono or bidentate $\mathrm{N}$ donor ligands-I. 1-benzylimidazole derivatives. Polyhedron. 1996;15(8):1263-1276.

[34] Liu D, Kwasniewska K. An improved agar plate method for rapid assessment of chemical inhibition to microbial populations. Bulletin of Environmental Contamination and Toxicology. 1981;27(3):289-294.

[35] Collins CH, Lyne PM, Grange JM. Microbiological Methods. 6th ed. London, UK: Butterworths; 1989.

[36] Saxena A, Tandon JP. Multinuclear magnetic resonance and related studies on some organotin(IV) complexes of dithiocarbazates. Polyhedron. 1983;2:443.

[37] Thornberry HH. A paper-disk plate method for the quantitative evaluation of fungicides and bactericides. Phytopathology. 1950;40:419-429.

[38] Garrod LP, Lambert HP, O'Grady F. Antibiotic and Chemotherapy. 5 ed. Edinburgh, Scotland: Churchill Livingstone; 1981.

[39] Singh HL, Khungar B, Tripaati UD, Varshney AK. Spectral and antimicrobial studies of organotin(IV) complexes with bidentate Schiff bases having nitrogen and sulphur donor ligands. Main Group Metal Chemistry. 2001;24:5. 


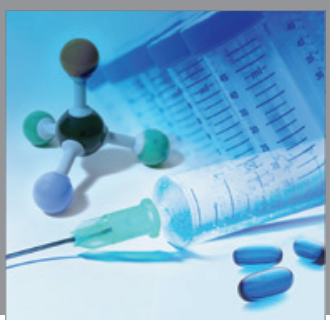

International Journal of

Medicinal Chemistry

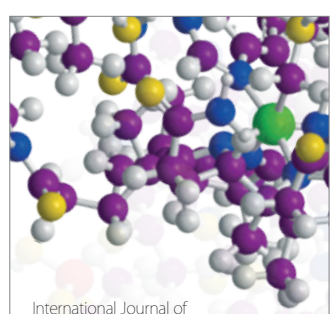

Carbohydrate Chemistry

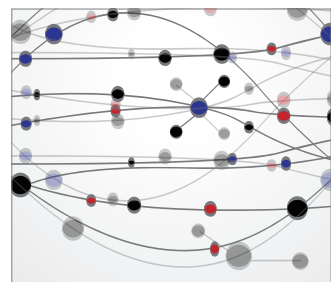

The Scientific World Journal
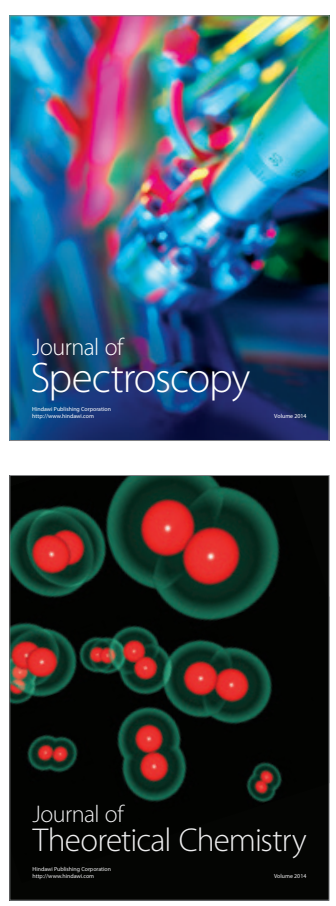
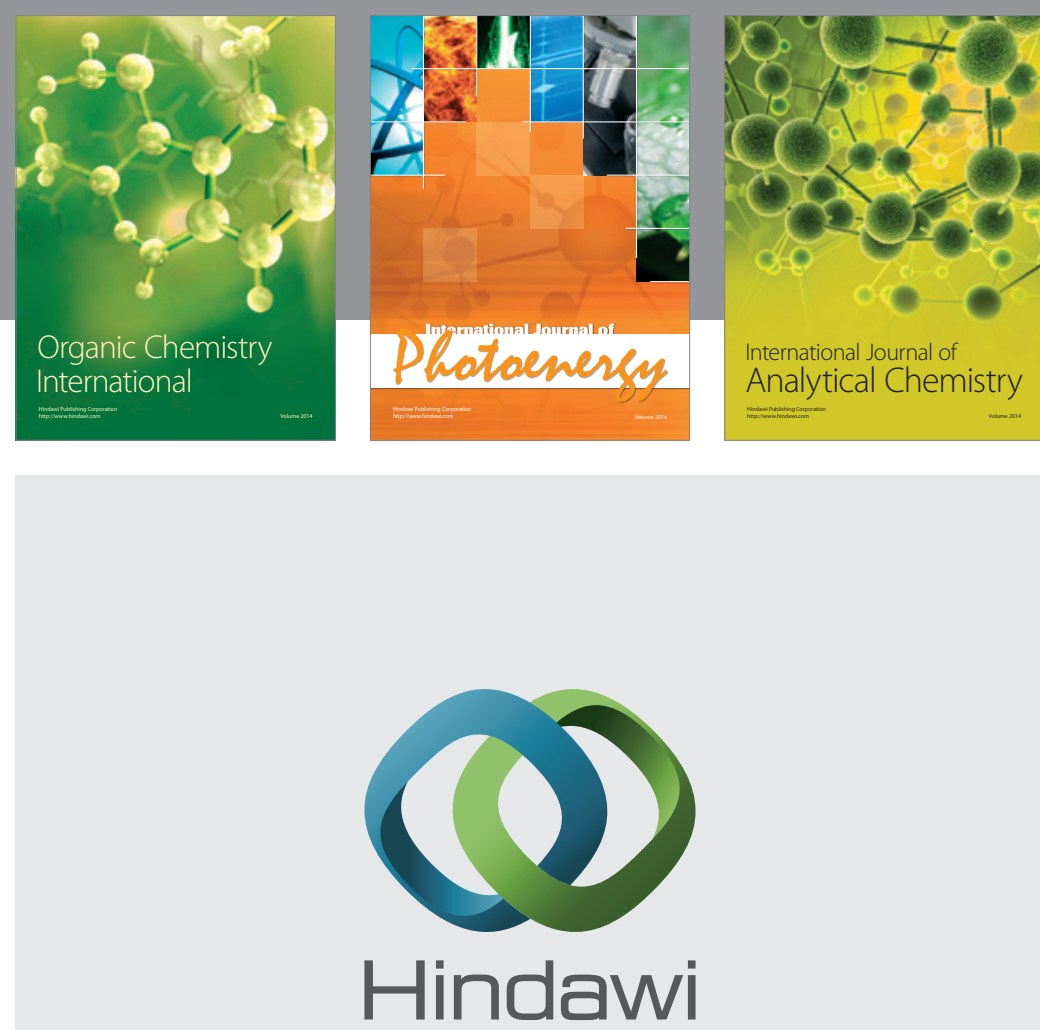

Submit your manuscripts at

http://www.hindawi.com
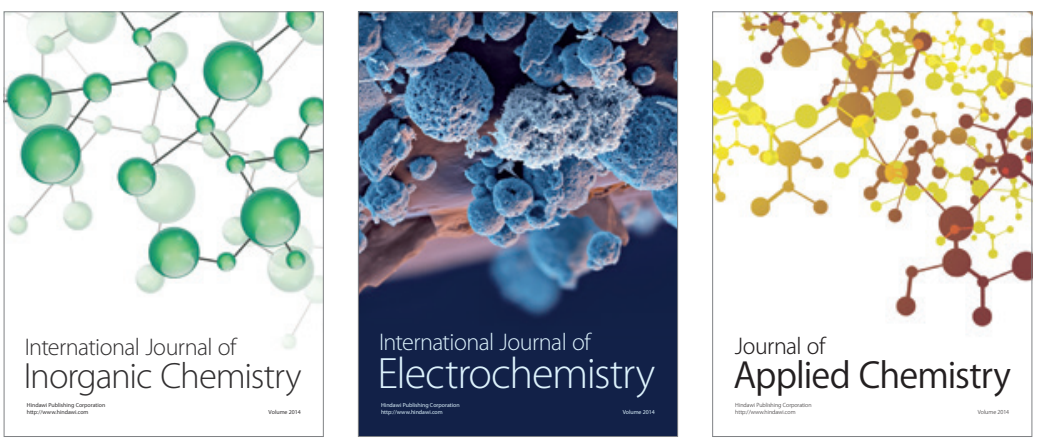

Journal of

Applied Chemistry
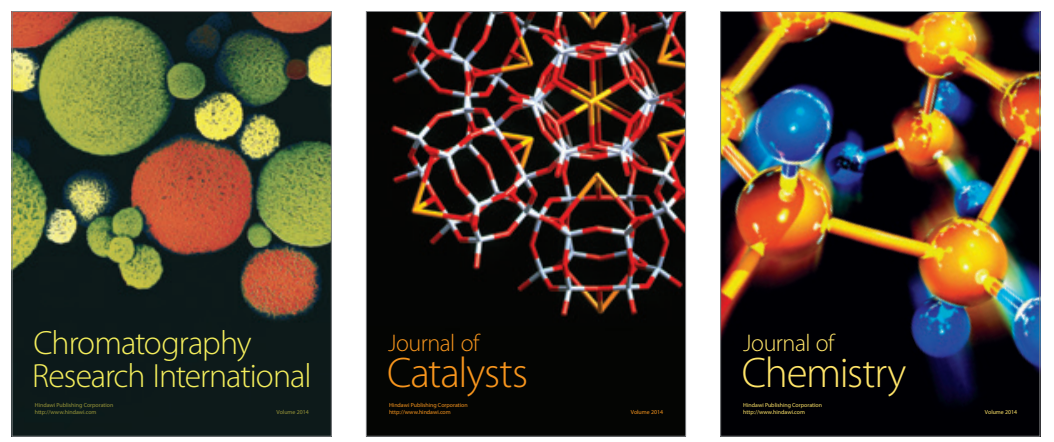
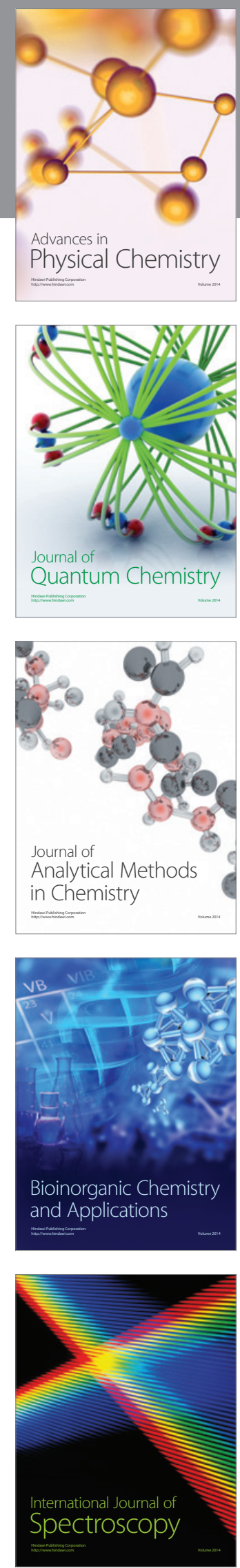